\title{
Magnitude and seasonality of wetland methane emissions from the Hudson Bay Lowlands (Canada)
}

\author{
C. A. Pickett-Heaps ${ }^{1, *}$, D. J. Jacob ${ }^{1}$, K. J. Wecht ${ }^{1}$, E. A. Kort ${ }^{1}$, S. C. Wofsy ${ }^{1}$, G. S. Diskin ${ }^{2}$, D. E. J. Worthy ${ }^{3}$, \\ J. O. Kaplan ${ }^{4}$, I. Bey ${ }^{5}$, and J. Drevet ${ }^{6}$ \\ ${ }^{1}$ School of Engineering and Applied Sciences \& Department of Earth and Planetary Sciences, Harvard University, \\ Cambridge MA 02138, USA \\ ${ }^{2}$ NASA Langley Research Center, Hampton, Virginia, USA \\ ${ }^{3}$ Environment Canada, Toronto, Ontario, Canada \\ ${ }^{4}$ Environmental Engineering Institute, École Polytechnique Fédérale de Lausanne, Lausanne, Switzerland \\ ${ }^{5}$ Center for Climate Systems Modeling (C2SM), ETH Zürich, Universitätstrasse 16, Zürich, Switzerland \\ ${ }^{6}$ Laboratoire de Modélisation de Chimie Atmosphérique, École Polytechnique Fédérale de Lausanne, Lausanne, Switzerland \\ * current address: CSIRO - Marine and Atmospheric Research, GPO Box 3023, Canberra, ACT, 2601, Australia
}

Received: 2 August 2010 - Published in Atmos. Chem. Phys. Discuss.: 30 September 2010

Revised: 29 March 2011 - Accepted: 30 March 2011 - Published: 27 April 2011

\begin{abstract}
The Hudson Bay Lowlands (HBL) is the second largest boreal wetland ecosystem in the world and an important natural source of global atmospheric methane. We quantify the HBL methane emissions by using the GEOS-Chem chemical transport model to simulate aircraft measurements over the HBL from the ARCTAS and pre-HIPPO campaigns in May-July 2008, together with continuous 2004-2008 surface observations at Fraserdale (southern edge of HBL) and Alert (Arctic background). The difference in methane concentrations between Fraserdale and Alert is shown to be a good indicator of HBL emissions, and implies a sharp seasonal onset of emissions in late May (consistent with the aircraft data), a peak in July-August, and a seasonal shut-off in September. The model, in which seasonal variation of emission is mainly driven by surface temperature, reproduces well the observations in summer but its seasonal shoulders are too broad. We suggest that this reflects the suppression of emissions by snow cover and greatly improve the model simulation by accounting for this effect. Our resulting best estimate for HBL methane emissions is $2.3 \mathrm{Tg} \mathrm{a}^{-1}$, several-fold higher than previous estimates (Roulet et al., 1994; Worthy et al., 2000).
\end{abstract}

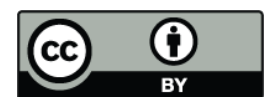

Correspondence to: C. A. Pickett-Heaps (christopher.pickett-heaps@csiro.au)

\section{Introduction}

Methane is the second most important anthropogenic greenhouse gas after carbon dioxide (IPCC, 2007). Methane concentrations have increased from $700 \mathrm{ppbv}$ in the preindustrial atmosphere to $1700 \mathrm{ppbv}$ by the early $1990 \mathrm{~s}$ (Etheridge et al., 1998). This increase is presumably driven by direct emissions from industry and agriculture (IPCC, 2007), but could also reflect changes in the chemical sink (reaction with the $\mathrm{OH}$ radical) and the effects of climate change on natural emissions (Worthy et al., 2000). Wetlands are the largest natural source of methane and are highly sensitive to changes in climate (Kaplan et al., 2006), especially in the boreal zone (Zhuang et al., 2006; Sitch et al., 2007). Here we use aircraft observations over the Hudson Bay Lowlands in northern Ontario as well as surface observations at Fraserdale and Alert to better quantify this boreal wetland source.

Methane is produced in boreal wetlands by heterotrophic respiration of partially decomposed organic material under anoxic conditions. As it rises to the surface, it may encounter oxic conditions resulting in oxidation. The remaining methane escapes to the atmosphere (Walter et al., 2001). Production of methane primarily depends on soil temperature, and the distribution of anoxic and oxic zones depends primarily on the water table level (Pelletier et al., 2007; Moore et al., 1994). Compounding this complexity in boreal wetland emissions is the seasonal thaw that propagates from the surface to depth (Dunn et al., 2009; Wania et al., 2009).

Published by Copernicus Publications on behalf of the European Geosciences Union. 
The Hudson Bay Lowlands (HBL) is an ecologically significant and well-studied boreal wetlands region (e.g. Glooschenko et al., 1994). It is (after the West Siberian wetlands) the second largest semi-continuous wetland region in the world, covering an area of $320000 \mathrm{~km}^{2}$ or about $10 \%$ of the total area covered by boreal wetlands (Wang et al., 2008; Glooschenko et al., 1994). The ABLE-3B/NOWES airborne and ground campaign conducted in the summer of 1990 estimated an annual methane emission of $0.5 \pm 0.3 \mathrm{Tg} \mathrm{a}^{-1}$ from the HBL (Roulet et al., 1994). Worthy et al. (2000), using inverse methods to interpret observations from the Alert and Fraserdale Canadian sites, obtained a similar estimate of 0.2 $0.5 \mathrm{Tg} \mathrm{a}^{-1}$. These estimates seem low compared to global inversion studies that infer total boreal wetland emissions of 27-38 $\mathrm{Tg} \mathrm{a}^{-1}$ (Hein et al., 1997; Wang et al., 2004; Bousquet et al., 2006), although Chen and Prinn (2006) obtained an estimate of $7 \mathrm{Tg} \mathrm{a}^{-1}$. Typically, the HBL is assumed to contribute $10 \%$ to global boreal wetland emissions.

The above inconsistencies point to the need for a better understanding of methane emissions from the HBL as a window into the global boreal wetland source. We exploit here methane concentration measurements from the ARCTAS and Pre-HIPPO aircraft campaigns in May-July 2008 (Fig. 1), together with long-term surface data from Environment Canada at Fraserdale $\left(81.6^{\circ} \mathrm{W}, 49.9^{\circ} \mathrm{N}\right)$ and Alert $\left(62.5^{\circ} \mathrm{W}, 82.5^{\circ} \mathrm{N}\right)$. We interpret these data using a global bottom-up scheme for wetland emissions implemented in the GEOS-Chem chemical transport model (CTM). The ARCTAS airborne campaign based in Cold Lake, Alberta (Jacob et al., 2010) conducted three flights over the HBL in early July, while the Pre-HIPPO campaign based in Boulder, Colorado (Pan et al., 2010) conducted 2 flights in the region in May-June.

\section{Model description}

We use the GEOS-Chem CTM originally described by Bey et al. (2001) in a methane simulation for 2004-2008 to interpret the aircraft and surface observations. GEOS-Chem is driven by GEOS-5 analyzed meteorological data from the NASA Global Modeling and Assimilation Office (GMAO). The GEOS-5 data have $1 / 2^{\circ} \times 2 / 3^{\circ}$ (lat, lon) horizontal resolution with 72 vertical levels and 6-h temporal resolution (3$\mathrm{h}$ for surface variables and mixing depths). The horizontal resolution is degraded here to $2^{\circ} \times 2.5^{\circ}$ for input to GEOSChem.

The methane simulation in GEOS-Chem was originally described by Wang et al. (2004), and subsequently improved and updated by Drevet et al. (2011). Major sources include anthropogenic emissions from EDGAR 4.0 (European Commission, 2009), natural emissions from wetlands as described below, and GFED2 biomass burning emissions (Giglio et al., 2006). Chemical loss of methane is computed using a global 3-D archive of monthly average $\mathrm{OH}$

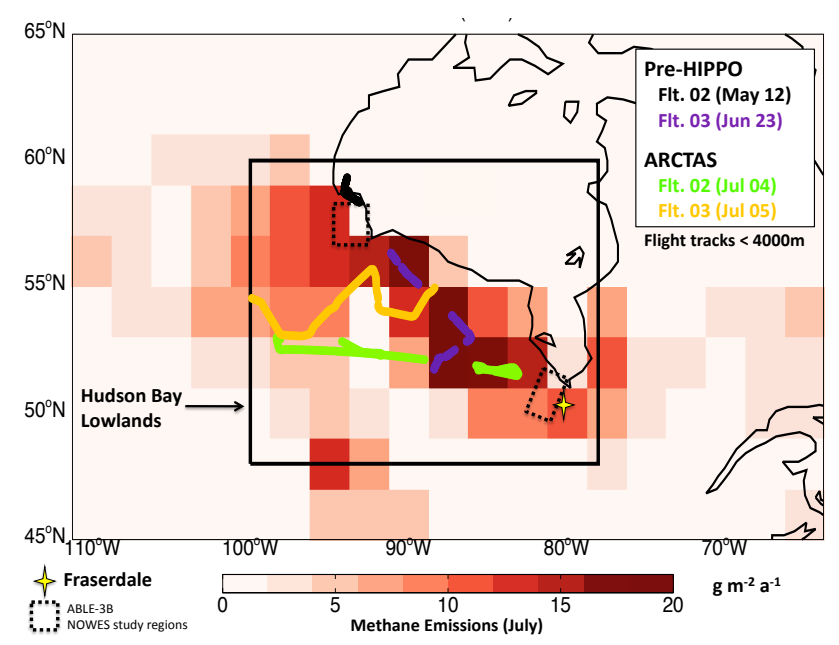

Fig. 1. ARCTAS and Pre-HIPPO flight tracks over the Hudson Bay Lowlands (HBL) below $4 \mathrm{~km}$, superimposed on a map of GEOSChem methane emissions for July 2008. The locations of Fraserdale and of the two ABLE-3B/NOWES study regions are also shown. The black rectangle encompasses the HBL region as defined in the present study.

concentrations from a GEOS-Chem simulation of tropospheric chemistry. The mean tropospheric $\mathrm{OH}$ concentration is $10.8 \times 10^{5}$ molecules $\mathrm{cm}^{-3}$, typical of current models (a global model inter-comparison by Shindell et al. (2006) gives a mean value of $11.1 \pm 1.7 \times 10^{5}$ molecules $\mathrm{cm}^{-3}$ ). The corresponding tropospheric lifetime of methylchloroform against oxidation by $\mathrm{OH}$ is $5.3 \mathrm{yr}$, within the range constrained by observations (Prinn et al., 2005). Additional minor sinks for methane in the model include stratospheric oxidation prescribed as a constant decay (Wang et al., 2004) and soil absorption (from EDGAR 4.0).

The wetlands emission scheme in GEOS-Chem is based on Kaplan (2002). The scheme applies methane emission factors to heterotrophic respiration rates in tropical and boreal wetlands, following algorithms described by Kaplan et al. (2002), Sitch et al. (2003) and Bergamaschi et al. (2007). The emission flux $E$ (molecules $\mathrm{CH}_{4} \mathrm{~m}^{-2} \mathrm{~s}^{-1}$ ) for each model grid square is given by:

$$
E=\delta W F \beta A e^{\frac{-E_{0}}{T-T_{0}}} \sum_{i=1}^{2} \frac{C_{i}}{\tau_{i}}
$$

where $C_{1}$ and $C_{2}\left(\mathrm{~mol} \mathrm{C} \mathrm{m}^{-2}\right)$ are soil and litter carbon pools, respectively, specified on a $2^{\circ} \times 2.5^{\circ}$ grid by the LundPotsdam-Jena dynamic global vegetation model (Sitch et al., 2003). These pools have fixed residence times $\tau_{1}=32 \mathrm{yr}$ and $\tau_{1}=2.8 \mathrm{yr}$ from Sitch et al. (2003). The Arrhenius factor with $A=1.0 e^{+3}, E_{0}=309 \mathrm{~K}$, and $T_{0}=227 \mathrm{~K}$ (Lloyd and Taylor, 1994) specifies the temperature dependence of respiration. The soil temperature $T$ is taken here as the GEOS-5 skin temperature. The methane emission factor is 
$\beta=3 \times 10^{-2} \mathrm{~mol} \mathrm{CH}_{4}$ per mol C respired (Christensen et al., 1996). An additional scaling factor $F$ is used to match observed ecosystem fluxes of methane, separately for tropical (T) and boreal (B) wetlands:

$F=\alpha \cdot F_{\mathrm{T}}+(1-\alpha) \cdot F_{\mathrm{B}}$

where $\alpha=\min \left(\exp \left[\left(\bar{T}-T_{1}\right) / 8\right], 1\right), \bar{T}(\mathrm{~K})$ is the mean monthly soil temperature taken here as the GEOS-5 skin temperature, and $T_{1}=303.15 \mathrm{~K}$. Scaling factors $F_{\mathrm{T}}=0.14$ and $F_{\mathrm{B}}=0.005$ were derived by J. Kaplan and J. Drevet (personal communication, 2009) to match published emission estimates for the Amazon (Melack et al., 2004) and boreal wetlands (Hein et al., 1997; Wang et al., 2004). Finally, $W$ in Eq. (1) represents the maximum potential fraction of wetland coverage for the grid square, as obtained from various databases described by Kaplan et al. (2002) and Bergamaschi et al. (2007). Whether a wetland is actually present $(\delta=1)$ or not $(\delta=0)$ over that fraction $W$ at any given time depends on the level of the water table, which we diagnose using GEOS-5 soil moisture as a proxy following Bergamaschi et al. (2007). Wetlands are present if the soil moisture exceeds a specified threshold of 0.1 for the ratio between the soil water content and the porosity of the soil (J. O. K. Kaplan, personal communication, 2009)

Annual emissions for the HBL (geographically defined as $50^{\circ} \mathrm{N}-60^{\circ} \mathrm{N}, 75^{\circ} \mathrm{W}-96^{\circ} \mathrm{W}$ ) computed in the above manner in GEOS-Chem average 2.9 $\mathrm{Tg} \mathrm{a}^{-1}$ for 2004-2008, with the spatial distribution shown in Fig. 1. This estimate is much larger than the previous HBL emission estimates of Roulet et al. (1994) and Worthy et al. (2000).

\section{Constraints on HBL methane emissions}

We examine the consistency of the GEOS-Chem methane emissions with the aircraft data from Pre-HIPPO and ARCTAS, and the surface data from Fraserdale and Alert. The DACOM tunable diode laser instrument used in ARCTAS (Sachse et al., 1987) has an estimated accuracy/precision of $1 \% / 0.1 \%$. The quantum cascade laser instrument used in Pre-HIPPO has an estimated accuracy and precision of $0.25 \%$. The surface measurements at Fraserdale are obtained by gas chromatography on samples collected from a 40-m high tower and have an accuracy/ precision of $1 \% / 0.2 \%$ (Worthy et al., 2003). Similar specifications apply to the surface measurements at Alert.

Figure 2 shows the ensemble of aircraft vertical profiles over the HBL from 12 May (Pre-HIPPO) to 5 July (ARCTAS). We excluded stratospheric air as diagnosed by a molar $\mathrm{O}_{3} / \mathrm{CO}$ ratio exceeding 1.25 (Hudman et al., 2006) and fire plumes as diagnosed by $\mathrm{CO}$ exceeding $200 \mathrm{ppbv}$. The latter filter effectively removed biomass burning influence from the data set as inferred from correlation between methane and CO. The HBL methane enhancements in Fig. 2 can thus be reliably attributed to wetland emissions.
The ARCTAS observations on 4-5 July show strong boundary layer enhancements over the HBL. The Pre-HIPPO flight on 12 May shows no boundary layer enhancement while that on 23 June shows a moderate enhancement. Observers on the Pre-HIPPO aircraft reported snow cover over the HBL on 12 May but not on 23 June. For comparison with the aircraft we sample the model at the time and location of the flights. We see in Fig. 2 that the model provides a good simulation of the boundary layer structure for the different flights, the enhancement observed in ARCTAS, and the sharp springtime transition from May to July. However, model overestimation is evident for the 23 June profile.

To further investigate the magnitude and seasonal onset of HBL emissions we used 2004-2008 surface data at Fraserdale and Alert collected by Environment Canada, with Alert serving as an Arctic background site against which the HBL influence at the Fraserdale downwind site can be referenced (Worthy et al., 1998). For Fraserdale we sample the daily data averaged over the 1700-1900 local time window, when the surface measurements are most representative of a relatively deep mixed layer (Worthy et al., 1998), and further select for surface winds from the northern quadrants, when direct influence from the HBL can be expected (Fig. 1). Selection for northerly winds retains $\sim 50 \%$ of the original data. We sample Alert data for the same times at Fraserdale in order to facilitate analysis of the difference between the two sites as discussed later.

Figure 3 shows the observed seasonal variations at Fraserdale and Alert for 2004-2008. The observations at Alert show a July minimum due to chemical loss in the Northern Hemisphere. The model minimum lags 4-6 weeks behind, an offset that can be attributed to background error in the seasonal variation of sources, transport, or $\mathrm{OH}$ concentrations. The observations at Fraserdale follow the seasonal variation at Alert in winter-spring but deviate in late May toward an August maximum, ostensibly due to emissions from the HBL. The model shows the same seasonal deviation at Fraserdale relative to Alert but shifted 6 weeks early. A model sensitivity simulation with no HBL emissions (also shown in Fig. 3) confirms that the seasonal deviation between Fraserdale and Alert is due primarily to HBL emissions. The model shows multiple seasonal peaks at Fraserdale (late June, late August, early November) compared to a single observed peak, but this fine structure reflects fluctuations in the background rather than HBL emissions as discussed below.

Although Fraserdale is at the southern end of the HBL and the data are collected at only $40 \mathrm{~m}$ altitude, they appear to be reasonably representative of the HBL. As a test, we partitioned the HBL into northern and southern halves and examined the model sensitivity of Fraserdale to emissions from each half. We found no significant difference. We also found no significant difference in methane concentrations when sampling the model at different altitudes over Fraserdale up to $500 \mathrm{~m}$ (five model layers). 


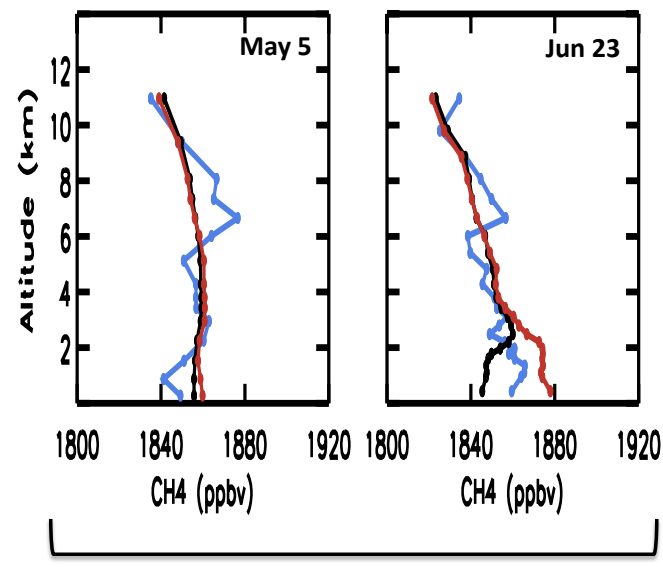

Pre-HIPPO
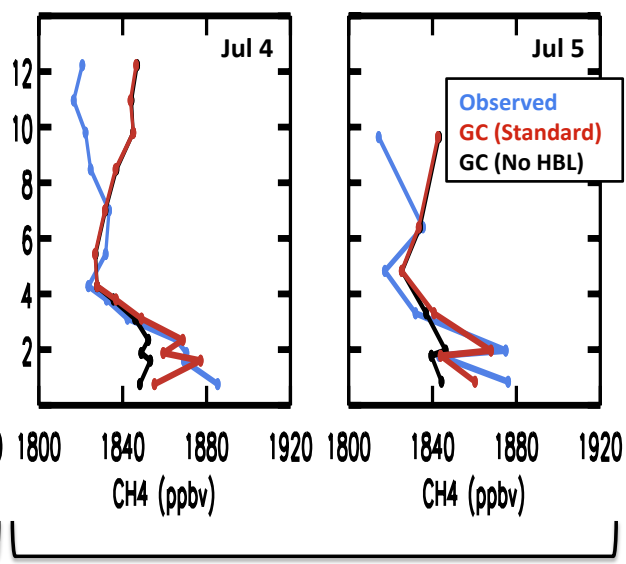

ARCTAS

Fig. 2. Methane vertical profiles from Pre-HIPPO and ARCTAS over the HBL (May-July 2008). Observations (blue) are compared to GEOS-Chem (GC) model vertical profiles sampled along the flight tracks at the flight times. The standard simulation (red) and a sensitivity simulation with no HBL emissions (black) are presented.

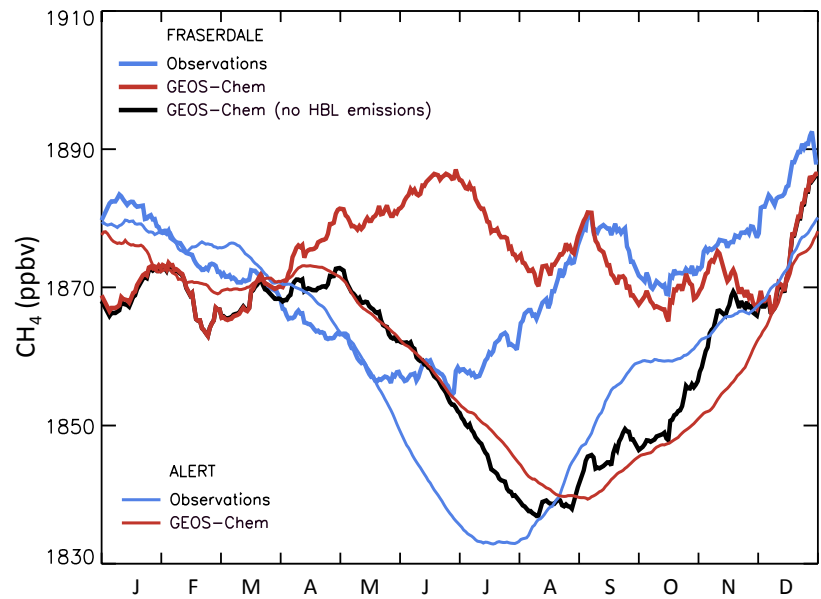

Fig. 3. Seasonal variation (2004-2008) of methane at Fraserdale and Alert. GEOS-Chem results are compared to observations. Also plotted is the model background concentration at Fraserdale as derived from a simulation with no HBL emissions. Data are daytime values smoothed with a 28-day moving average and then averaged over 5 yr. For Fraserdale we use only data associated with winds from the northern quadrants.

Figure 4 shows the seasonal variation of the difference in concentrations between Fraserdale and Alert $\left(\Delta \mathrm{CH}_{4}\right)$, illustrating more precisely the methane flux signature from the HBL. Here we assume that Alert provides a reasonable measure of background concentrations at Fraserdale; this is supported in the model by the comparison in Fig. 3 of the model simulation at Alert (thin blue line) and at Fraserdale in the absence of HBL emissions (thick black line). We find that the multi-peak structure of model concentrations at Fraserdale in June-November (Fig. 3) is reduced when corrected for the

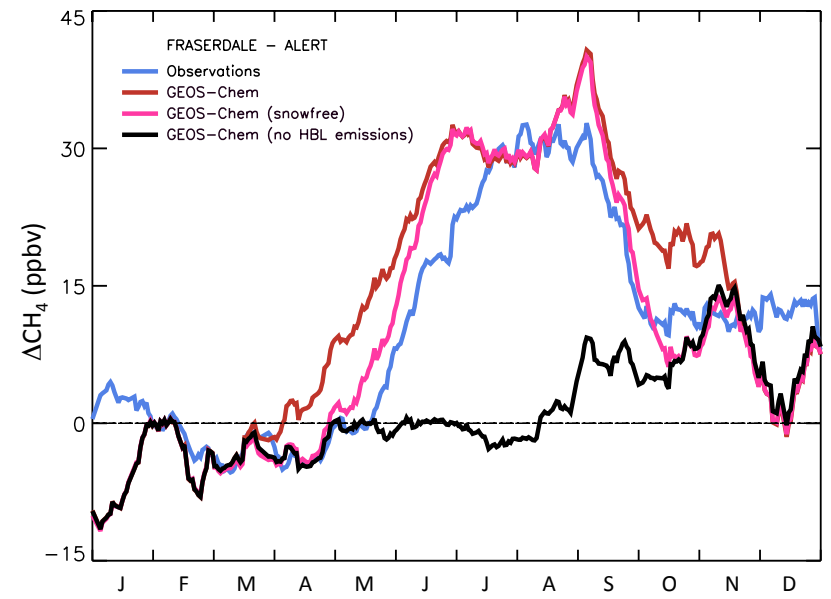

Fig. 4. Mean seasonal differences in $\mathrm{CH}_{4}$ concentration between Fraserdale and Alert $\left(\Delta \mathrm{CH}_{4}\right)$ for 2004-2008 (data in Fig. 3). Observations (blue) are compared to the standard GEOS-Chem simulation, a sensitivity simulation restricting emissions to snow-free ground, and a sensitivity simulation with no HBL emissions.

Alert background (Fig. 4). More importantly, we find that any residual multi-peaks in modeled $\Delta \mathrm{CH}_{4}$ are associated more with changes in the model background at Fraserdale relative to that at Alert than in HBL model emissions. Temporal fluctuations during those two months in the model may also reflect the greater variability in surface temperatures (used in the model to compute methane emission) than in actual soil temperatures. Heat transfer in the soil column would be expected to dampen temporal variability in soil temperatures.

The observed onset of HBL methane emissions in late May, as seen in Fig. 4, is consistent with the aircraft 
observations discussed above and with previous field studies in nearby James Bay peatlands that suggest an onset of emissions in mid-May (Pelletier et al., 2007). By contrast, we see from Fig. 4 that HBL emissions in the model begin in early April. In addition, the observations indicate a seasonal shutdown of HBL emissions in September whereas in the model these emissions persist into October. The early onset of model emissions was not apparent in comparison with the Pre-HIPPO profile on 12 May in Fig. 2, but that is because of delayed spring warming in 2008 and because that flight profile sampled the northern edge of the HBL (Fig. 1).

The premature onset of HBL methane emissions in the model likely reflects the use of skin temperature as proxy for soil temperature. Seasonal increases in soil temperature at depth lag behind the land surface during the spring thaw. We attempted to impose in the model a time lag for soil heating by using the standard heat transport parameterization of Campbell and Norman (1998) with thermal diffusivities from Sitch et al. (2003), but the resulting delay in the onset of emissions was insufficient. Instead we identified persistent snow cover in the GEOS-5 data well past the model onset in model emissions. Snow cover would insulate the underlying soil from warming, inhibiting methanogenesis in spring, and would also trap methane in the autumn (Friborg et al., 1997). Consequently we modified the model to restrict emissions to snow-free regions. Figure 4 shows that this mostly corrects the model biases in the spring and autumn, although there is still a small lag of 1-2 weeks in the spring. This additional delay might reflect a period of time required for the underlying peatlands to thaw before methanogenesis ensues (Dunn et al., 2009). Comparison with the aircraft profiles in Fig. 2 is unaffected by the delayed onset in model emissions. The resulting annual reduction in model HBL emissions is $20 \%$ $\left(2.3 \mathrm{Tg} \mathrm{a}^{-1}\right.$ vs. $\left.2.9 \mathrm{Tg} \mathrm{a}^{-1}\right)$.

The model temporal variability of methane emissions in the snow-free season is driven largely by surface temperature (Eq. 1), and this appears adequate to match the observed July-August maximum of HBL emissions (Fig. 4). Previous studies of boreal wetlands have pointed out the sensitivity of emissions to changes in the level of the water table (Moore et al., 1994; Pelletier et al., 2007). However, the flat topography of the HBL results in poor drainage and maintains persistent wetland coverage throughout the summer.

Figure 5 shows the interannual variation of HBL model emissions for 2004-2008 as driven by temperature and snow cover. The seasonal onset of emission can vary by a month from year to year. There is much less year-to-year variability in the fall shutdown of emissions. The mean annual emission for the $5 \mathrm{yr}$ is $2.3 \pm 0.3 \mathrm{Tg} \mathrm{a}^{-1}$.

\section{Comparison to ABLE-3B/NOWES estimates}

The ABLE-3B/NOWES surface and aircraft field study in July 1990 previously reported an annual emission estimate

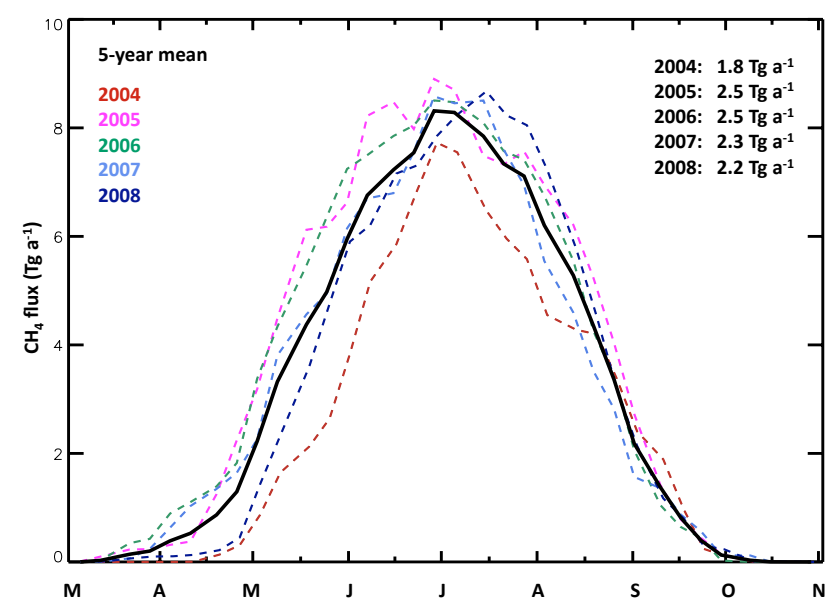

Fig. 5. Seasonal variation of HBL methane emissions simulated by the model for 2004-2008. Values are integrated spatially over the HBL domain $\left(50^{\circ} \mathrm{N}-60^{\circ} \mathrm{N}, 75^{\circ} \mathrm{W}-96^{\circ} \mathrm{W}\right)$ and smoothed temporally with a 4 -week moving average. Also tabulated are annual emission estimates for individual years.

of $0.5 \pm 0.2 \mathrm{Tg} \mathrm{a}^{-1}$ for the HBL (Harris et al., 1994; Roulet et al., 1994). This is considerably less than our best estimate of $2.3 \mathrm{Tg} \mathrm{a}^{-1}$, and would be inconsistent with the PreHIPPO and ARCTAS data of Fig. 2 as well as the Fraserdale $\triangle \mathrm{CH}_{4}$ data of Fig. 4. The ABLE-3B/NOWES estimate was obtained by extrapolation of direct flux measurements at surface sites, using wetland coverage derived from satellite and aerial imagery. The surface sites and supporting aircraft eddy correlation flux measurements were located in two small study areas at the southern and northern edges of the HBL (Fig. 1). Roulet et al. (1994) reported mean June-October emission estimates for the southern and northern study areas of $3.4 \mathrm{~g} \mathrm{~m}^{-2} \mathrm{a}^{-1}$ and $6.3 \mathrm{~g} \mathrm{~m}^{-2} \mathrm{a}^{-1}$, respectively, from their surface measurements. Aircraft measurements over these same regions in July yielded consistent mean fluxes of $5 \pm 3 \mathrm{~g} \mathrm{~m}^{-2} \mathrm{a}^{-1}$ and $4 \pm 6 \mathrm{~g} \mathrm{~m}^{-2} \mathrm{a}^{-1}$ respectively. These values agree with our flux estimates of $\sim 5 \mathrm{~g} \mathrm{~m}^{-2} \mathrm{a}^{-1}$ for both ABLE-3B/NOWES regions in July (Fig. 1). Roulet et al. (1994) went on to infer annual mean emissions by taking their June-October measurements to be representative of snow-free conditions and assuming zero emissions for snowcovered ground. This is consistent with our findings.

The large difference between our estimate of HBL emission estimate and that of Roulet et al. (1994) thus lies in the spatial extrapolation to the scale of the HBL. We see from Fig. 1 that our emissions are much higher in the mid-section of the HBL than in the ABLE-3B/NOWES study regions. The boundary layer methane enhancements observed from the ABLE-3B aircraft ( $\sim 30 \mathrm{ppbv})$ were indeed much lower than the mean value of $60 \mathrm{ppbv}$ observed on the ARCTAS flights (Fig. 2). 


\section{Conclusions}

Aircraft observations over the Hudson Bay Lowlands (HBL) in May-July 2008 show a seasonal onset of methane emissions in June and $60 \mathrm{ppbv}$ enhancements in the boundary layer in July. Surface observations at Fraserdale (just south of the HBL), when referenced against a background Arctic site (Alert) to isolate the HBL contribution, indicate a seasonal onset of methane emission in late May, a peak emission from mid-July to the end of August, and a sharp decrease in September. The GEOS-Chem model including a standard methane emission scheme for boreal wetlands can successfully reproduce these observations except for a premature springtime onset and a delayed fall shut-off. Seasonal variation of wetland emission in the model is mainly driven by surface temperature. We find that accounting in addition for suppression of emission by snow cover corrects the model biases in spring and fall. The variability in the model is still larger than observed and this could reflect dampening of soil temperature fluctuations relative to the surface. Our resulting best estimate of HBL methane emissions is $2.3 \mathrm{Tg} \mathrm{a}^{-1}$, much higher than previous estimates for the region (Roulet et al., 1994; Worthy et al., 2000). We argue that this reflects gradients of methane emission within the HBL that were not previously accounted for.

Acknowledgements. This work was supported by the US National Science Foundation and by the Tropospheric Chemistry Program of the National Aeronautics and Space Administration. We thank the reviewers for useful comments.

Edited by: A. Stohl

\section{References}

Bergamaschi, P., Frankenberg, C., Meirink, J.F., Krol, M., Dentener, F., Wagner, T., Platt, Y., Kaplan, J.O., Kroner, S., Heimann, M., Dlugokencky, E. J., and Goede, A.: Satellite cartography of atmospheric methane from SCIAMACHY on board ENVISAT: 2. Evaluation based on inverse model simulations, J. Geophys. Res., 112, D02304, doi:10.1029/2006JD007268, 2007.

Bey, I., Jacob, D. J., Yantosca, R. M., Logan, J. A., Field, B. D., Fiore, A. M., Li, Q. B., Lui, H. G. Y., Mickley, L. J., and Schultz, M. G.: Global modeling of tropospheric chemistry with assimilated meteorology: Model description and evaluation, J. Geophys. Res., 106(D19), 23073-23095, 2001.

Bousquet, P., Ciais, P., Miller, J. B., Dlugokencky, E. J., Hauglustaine, D. A., Prigent, C., Werf, G. R. Van der, Peylin, P., Brunke, E.-G., Carouge, C., Langenfelds, R. L., Lathiere, J., Papa, F., Ramonet, M., Schmidt, M., Steele, L. P., Tyler, S. C., and White, J.: Contribution of anthropogenic and natural sources to atmospheric methane variability, Nature, 443, 439443, doi:10.1038/nature05132, 2006.

Campbell, J. S. and Norman, J. M.: An introduction to Environmental Biophysics, 28 pp., Springer, 1998.

Chen, Y. H. and Prinn, R. G.: Estimation of atmospheric methane emissions between 1996 and 2001 using a three-dimensional global chemical transport model, J. Geophys. Res., 111, D10307, doi:10.1029/2005JD006058, 2006.

Christensen, T. R., Prentice, I. C., Kaplan, J. O., Haxeltine, A., and Sitch, S.: Methane flux from northern wetlands and tundra, Tellus, 48, 652-661, doi:10.1034/j.1600-0889.1996.t01-4-00004.x, 1996.

Drevet, J., Bey, I., Kaplan, J., Generoso, G., and Koumoutsaris, S.: A modeling studyof the global methane budget over the period 1990-2004: 1. Model description and evaluation, in preparation, 2011.

Dunn, A. L., Wofsy, S. C., and Bright, A. H.: Landscape heterogeneity, soil climate, and carbon exchange in a boreal black spruce forest, Ecol. Appl., 19(2), 495-504, 2009.

Etheridge, D. M., Steele, L. P., Francey, R. J., and Langenfelds, R. L.: Atmospheric methane between 1000AD and present: Evidence of anthropogenic emissions and climate variability, J. Geophys. Res., 103(D13), 15979-15993, 1998.

European Commission, Joint Research Centre (JRC)/Netherlands Environmental Assessment Agency (PBL). Emission Database for Global Atmospehric Research (EDGAR), release version 4.0. http://edgar.jrc.ec.europa.eu, 2009

Friborg, T., Christensen, T. R., and Søgarrd, H.: Rapid response of greenhouse gas emission to early spring thaw in a subarctic mire as shown by micrometeorological techniques, Geophys. Res. Lett., 24(23), 3061-3064, doi:10.1029/97GL03024, 1997.

Giglio, L., Csiszar, I., and Justice, C. O.: Global distribution and seasonality of active fires as observed with the Terra and Aqua Moderate Resolution Imaging Spectroradiometer (MODIS) sensors, J. Geophys. Res.-Biogeo., 111, G02016, doi:10.1029/2005JG000142, 2006.

Glooschenko, W., Roulet, N. T., Barrie, L. A., Schiff, H. I., and McAdie, H. G.: The Northern Wetlands Study (NOWES): An overview, J. Geophys. Res., 99(D1), 1423-1428, 1994.

Harriss, R. C., Wofsy, S. C., Hoell Jr., J. M., Bendura, R. J., Drewry, J. W., McNeal, R. J., Pierce, D., Rabine, V., and Snell, R. L.: The Arctic Boundary Layer Expedition (ABLE-3B): JulyAugust 1990, J. Geophys. Res., 99(D1), 1635-1643, 1994.

Hein, R. and Crutzen, P. J.: An inverse modeling approach to investigate the global atmospheric methane cycle, Global Biogeochem. Cy., 11(1), 43-76, 1997.

Hudman, R. C., Jacob, D. J., Turquety, S., Leibensperger, E. M., Murray, L. T., Wu, S., Gilliland, A. B., Avery, M., Bertram, T. H., Brune, W., Cohen, R. C., Dibb, J. E., Floke, F. M., Fried, A., Holloway, J., Neuman, J. A., Orville, R., Perring, A., Ren, X., Sachse, G. W., Singh, H. B., Swanson, A., and Wooldridge, P. J.: Surface and lightning sources of nitrogen oxides over the United States: Magnitudes, chemical evolution and outflow, J. Geophys. Res., 112, D12S05, doi:10.1029/2006JD007912, 2006.

IPCC: Climate Change 2007: The Physical Science Basis. Contribution of Working Group I to the Fourth Assessment. Report of the Intergovernmental Panel on Climate Change, edited by: Solomon, S., Qin, D., Manning, M., Chen, Z., Marquis, M., Averyt, K. B., Tignor, M., and Miller, H. L., Cambridge University Press, Cambridge, United Kingdom and New York, NY, USA, 996 pp., 2007.

Jacob, D. J., Crawford, J. H., Maring, H., Clarke, A. D., Dibb, J. E., Emmons, L. K., Ferrare, R. A., Hostetler, C. A., Russell, P. B., Singh, H. B., Thompson, A. M., Shaw, G. E., McCauley, E., Pederson, J. R., and Fisher, J. A.: The Arctic Research of the Com- 
position of the Troposphere from Aircraft and Satellites (ARCTAS) mission: design, execution, and first results, Atmos. Chem. Phys., 10, 5191-5212, doi:10.5194/acp-10-5191-2010, 2010.

Kaplan, J. O.: Wetlands at the Last Glacial Maximum: Distribution and methane emissions, Geophys. Res. Lett., 29(6), 1079, doi:10.1029/2001GL013366, 2002.

Kaplan, J. O., Folberth, G., and Hauglustaine, D. A.: Role of methane and biogenic volatile organic compound sources in late glacial and Holocene fluctuations of atmospheric methane concentration, Global Biogeochem. Cy., 20, GB2016, doi:10.1029/2005GB002590, 2006.

Lloyd, J. and Taylor, J. A.: On the temperature dependence of soil respiration, Funct. Ecol., 8, 315-323, 1994.

Melack, J., Hess, L. L., Gastil, M., Forsberg, B. R., Hamilton, S. K., Lima, I. B. T., and Novo, E. M. L. M.: Regionalization of methane emissions in the Amazon basin with microwave remote sensing, Glob. Change Biol., 10, 530-544, 2004.

Moore, T. R., Heyes, A., and Roulet, N. T.: Methane emissions from wetlands, southern Hudson Bay lowland, J. Geophys. Res., 99(D1), 1455-1467, 1994.

Pan, L. L., Bowman, K. P., Atlas, E. L., Wofsy, S. C., Zhang, F. Q., Bresch, J. F., Ridley, B. A., Pittman, J. V., Homeyer, C. R., Romashkin, P., and Cooper, W. A.: The Stratosphere-Troposphere Analyses of Regional Transport 2008 Experiment, B. Am. Meteorol. Soc., 91(3), p. 237, 2010.

Pelletier, L., Moore, T. R., Roulet, N. T., Garneau, M., and Beaulieu-Audy, V.: Methane fluxes from three peatlands in the La Grande Riviere watershet, James Bay lowland, Canada, J. Geophys. Res., 112, G01018, doi:10.1029/2006JG000216, 2007.

Prinn, R. G., Huang, J., Weiss, R. F., Cunnold, D. M., Fraser, P. J., Simmonds, P. G., McCulloch, A., Harth, C., Reimann, S., Salameh, P., O’Doherty, S., Wang, R. H. J., Porter, L. W., Miller, B. R., and Krummel, P. B.: Evidence for variability of atmospheric hydroxyl radicals over the past quarter century, Geophys. Res. Lett., 32, L07809, doi:10.1029/2004GL022228, 2005.

Roulet, N. T., Jano, A., Kelly, C. A., Klinger, L. F., Moore, T. R., Protz, R., Ritter, J. A., and Rouse, W. R.: Role of the Hudson Bay lowland as a source of atmospheric methane, J. Geophys. Res., 99(D1), 1439-1454, 1994.

Sachse, G. W., Hill, G. F., Wade, L. O., and Perry, M. G.: Fastresponse, high-precision carbon monoxide sensor using a tunable diode laser absorption technique, J. Geophys. Res., 92, 20712081, 1987.

Shindell, D. T., Faluvegi, G., Stevenson, D. S., Krol, M. C., Emmons, L. K., Lamarque, J. F., Petron, G., Dentener, F. J., Ellingson, K., Schultz, M. G., Wild, O., Amann, M., Atherton, C. S., Bergmann, D. J., Bey, I., Butler, T., Cofala, J., Collins, W. J., Derwent, R. G., Doherty, R. M., Drevet, J., Eskes, H. J., Fiore, A. M., Gauss, M., Hauglustaine, D. A., Horowitz, L. W., Isaksen, I. S. A., Lawrence, M. G., Montanaro, V., Muller, J. F., Pitari, G., Prather, M. J., Pyle, J. A., Rast, S., Rodriguez, J. M., Sanderson, M. G., Savage, N. H., Strahan, S. E., Sudo, K., Szopa, S., Unger, N., van Noije, T. P. C, and Zen, G.: Multimodel simulations of carbon monoxide: Comparison with observations and projected near-future changes, J. Geophys. Res., 111, D08302, doi:10.1029/2006JD007100, 2006.
Sitch, S., Smith, B., Prentice, I. C., Arneth, A., Bondeau, A., Cramer, W., Kaplan, J. O., Levis, S., Lucht, W., Sykes, M. T., Thonicke, K., and Venevsky, S.: Evaluation of ecosystem dynamics, plant geography and terrestrial carbon cycling in the LPJ dynamic global vegetation model, Glob. Change Biol., 9, 161185, 2003.

Sitch, S., McGuire, A. D., Kimball, J., Gedney, N., Gamon, J., Engstrom, R., Wolf, A., Zhuang, Q., Clein, J., and McDonald, K. C.: Assessing the carbon balance of circumpolar arctic tundra using remote sensing and process modeling, Ecol. Appl., 17(1), 213-234, 2007.

Walter B. P., Heimann, M., and Matthews, E.: Modeling modern methane emissions from natural wetlands 1: Model description and results, J. Geophys. Res., 106(D24), 34189-34206, 2001.

Wania, R., Ross, I., and Prentice, I. C.: Integrating peatlands and permafrost into a dynamic global vegetation model: 1. Evaluation and sensitivity of physical land surface processes, Global Biogeochem. Cy., 23, GB3014, doi:10.1029/2008GB003412, 2009.

Wang, J. S., Logan, J. A., McElroy, M. B., Duncan, B. N., Megretskaia, I. A. and Yantosca, R. M.: A 3-D model analysis of the slowdown and interannual variability in the methane growth rate from 1988 to 1997, Global Biogeochem. Cy., 18, GB3011, doi:10.1029/2003GB002180, 2004.

Wang, J. S., McElroy, M. B., Logan, J. A., Palmer, P. I., Chameides, W. L., Wang, Y., and Megretskaia, I. A., A quantitative assessment of uncertainties affecting estimates of global mean $\mathrm{OH}$ derived from methyl chloroform observations, J. Geophys. Res., 113, D12302, doi:10.1029/2007JD008496, 2008.

Worthy, D. E. J., Levin, I., Trivett, N. B. A., Kuhlmann, A. J., Hopper, J. F., and Ernst, M. K.: Seven years of continuous methane observations at a remote boreal site in Ontario, Canada, J. Geophys. Res., 103(D130), 15995-16007, 1998.

Worthy, D. E. J., Levin, I., Hopper, F., Ernst, M. K., and Trivett, N. B. A.: Evidence for a link between climate and northern wetland methane emissions, J. Geophys. Res., 105(D3), 4031-4038, 2000.

Worthy, D. E. J., Platt, A., Kessler, R., Ernst, M., and Racki, S.: The Greenhouse Gases Measurement Program, Measurement Procedures and Data Quality, In: Canadian Baseline Program; Summary of progress to 2002, Meteorological Service of Canada, Canada, 97-120, 2003.

Zhuang, Q., Melillo, J. M., Sarofim, M. C., Kicklighter, D. W., McGuire, A. D., Felzer, B. S., Sokolov, A., Prinn, R. G., Steudler, P. A., and $\mathrm{Hu}$, S.: $\mathrm{CO}_{2}$ and $\mathrm{CH}_{4}$ exchanges between land ecosystems and the atmosphere in northern high latitudes over the $21^{\text {st }}$ century, Geophys. Res. Lett., 33, L17403, doi:10.1029/2006GL026972, 2006. 